\title{
Public administration with collaborative governance-from the perspective of social resource distribution
}

\author{
XU Yan-qing \\ School of Political Science and Public Administration, Hainan University, \\ Haikou, P.R. China \\ e-mail:sunnyxu611@126.com
}

\begin{abstract}
The distribution of social resource is not only affected by social conditions such as economic, political and cultural factors, but also influencing society in return. Three distribution modes: market dominated invisible hand mode, government dominated visible hand mode, and non-governmental organization dominated the third hand mode all have certain kind of drawbacks. In the context of public administration with collaborative governance, market, government, and non-governmental organizations are in different fields, adopting diverse methods to allocate resources. These three parts learn from and impact each other, leading to the best resource exploitation, which realizes the maximization of social public benefit.
\end{abstract}

Keywords- collaborative governance; public administration; social resource; distribution; multi-centered

\section{INTRODUCTION}

Social resource is the basis of human society's survival and development, and the premise of social members' various activities. Generally speaking, social resource refers to everything society possessed or available to be adopted in the process of realizing the main bodies' objectives, or when the society is running, developing. The end of public administration is realizing the maximization of social public benefits through integrating and optimizing the distribution of social resources. Public administration exists long ago. When state and its attachment-government arouse, the relationship between government and the public appeared, resulted in management of social public affairs. However, a new framework of this kind of management activities - public administration finally turned out at the end of last century ${ }^{[1]}$. The most featured difference between the new framework and the old one is collaborative governance, which is based on the change from the failure of several single-centered distribution modes to multi-centered one.

\section{II . SINGLE-CENTERED SOCIAL RESOURCE DISTRIBUTION MODE: MARKET----GOVERNMENT----NON-GOVERNMENTA L ORGANIZATION}

A. "invisible hand": market dominated social resource distribution mode

Adam Smith, the founder of classical economy, believes government is the night watchman. He is opposed to government interfering too much with economic activities. Furthermore, he supports economic freedom.
He also emphasizes that market mechanism is the invisible hand that push economy award, optimizing all the social resources to achieve balanced production development and full employment. Meanwhile, he points out: "Every man, as long as he does not violate the laws of justice, is left perfectly free to pursue his own interest his own way, and to bring both his industry and capital into competition with those of any other man, or order of men. [2]" Neoclassical economy carries on Adam Smith's belief of economic freedom. They think consumer preference is like a baton, guiding resources the direction of allocation. At the same time, whether resources are distributed the most optimal is determinate by the satisfaction degree of consumers. Through marginal fine-tuning operations, market makes marginal contrast in various functions to promote the resources move to the best direction, reaching Pareto efficiency. Since firm belief in free market, neoclassical economists disagree with government involving in the distribution, for example, Friedrich August von Hayek, Robert Nozick, Milton Friedman, and so on.

Under the guidance of liberal economy theory, western countries carry out the market dominated resource distribution mode. On the basis of law of value and market mechanism, the distribution mode uses the abstract amount of currency to express the limitation of social resources, and is established through free exchange and free competition on the premise of clear property rights. Efficient distribution needs making most use of all kinds of information. The information structure, whose major content is price system, makes simple, clear, effective information available for and effectively taken advantage of by every participant of economic activities. So it improves rationality of distribution ${ }^{[3]}$

B. "visible hand": government dominated social resource distribution mode

1929-1933,the capitalist world economic crisis shocked the whole world. People came to realize that market is not as perfect as imagination, because it sometimes fails. Market dominated distribution mode has some problems: the economic balance through market adjustment which is a kind of afterwards adjustment is achieved by decentralized decision making. This is spontaneous and blind in considerable degree. The total effect of individual rational choice may be collective irrational behavior. Market can promote economic 
efficiency and development of production, however, it cannot bring balance and justice of social distribution structure automatically. The stronger becomes stronger, the weaker gets weaker. The Matthew Effect that wealth becomes more and more focused results in larger and larger gap between the income of the poor and the rich, the developed and the backward areas. When income gap is extremely large, resource cannot distribute morally best ${ }^{[3]}$. From the perspective of provision of public goods, since they are nonexclusive and noncompetitive, it is impossible for market to provide or the cost is so high. Considered fairness, justice and so many other things, market's provision of public goods lacks of efficiency in economy of scale, leading to market failure. However, lack of necessary public goods cannot satisfy social economy's need, decreasing distribution efficiency remarkably.

In this case, western dirigisme, represented by John Maynard Keynes, turned out. They think the invisible hand could face so many difficult positions. The only solution is giving up economic liberalism and implementing dirigisme thoroughly to achieve the balance between aggregate demand and aggregate supply of commodity through a visible hand. As long as nation intervenes in economy, and manage demand of national economy to balance aggregate supply and demand, it will overcome crisis and reach full employment. This kind of mode, dominated by government, distributes social resources through mandatory orders. Government monopoly and control which means unitary and one dimensional social resource control inclines to a balance state, based on certain technology level and mandatory power system , among kinds of social powers.

C. "the third hand": non-governmental social resource distribution mode

Under the guidance of Keynesianism, during most of 1950 s to 1960 s, western developed capitalist countries experienced economic recovery and booming. However, it didn't stay long. In 1970s, these countries fell into stagflation, so people questioned the visible hand theory by Keynes. Theory of public choice argues that government in real life is not always noble. Government chases for its own interests rather than public benefits, internal effects, is expressed vividly and incisively in "Money Politics" in capitalist countries.

Government's internal effect necessarily influences heavily on the distribution optimization under government intervening. Like external effect to market failure, internal effect is one of the significant reasons of government failure $^{[3]}$. Government cannot collect fees from supplier directly through exchange of clear price but rely on financial expense to maintain production and operation. It is hard to haggle over the cost, so it lacks direct benefit impetus to decrease cost and increase benefit. The planners and government's decision makers cannot collect complete information about what the society needs and how much it needs, so the plan they made must be blind which cannot meet the consumers' demand and go against resources distribution. What's more, as monopoly supplier of some public goods with pressing need, only government has the function and power to intervene or regulate this market externally. This monopoly without competition deprives government of pursue of efficiency and benefit, which wastes resource.

When government failure became the focus of the debate, the wave of mass organization revolution gradually grew up in academia. Hansmann thinks that nonprofit organizations must obey non-distribution constraint, so it doesn't reduce quality to pursue profit. If public goods' production is completed by this kind of nonprofit third-party organizations, the producers' fraud could be reduced significantly ${ }^{[4]}$. Burton A. Weisbrod believes the third party could be regarded as an independent power to realize the best combination of fairness and efficiency when providing public goods. Meanwhile, it is very significant avoiding government and private sectors destroying public benefits ${ }^{[5]}$. Non-governmental organizations are nonprofit, public morality based, autonomous, friendly, community based. The non-governmental dominated distribution mode utilizes routine, custom, moral principles, public voice and so many other ethical principles to deal with social resources. The moral rule is, in fact, the reflection of resource constraint in human ideology. Social members view the moral rules as standard of mutual supervision. This social management method and distribution way is running through negotiation and coordination.

\section{III.“MARKET FAILURE”, “GOVERNMENT FAILURE”, "VOLUNTEER FAILURE”: MULTI-CENTERED SOCIAL RESOURCE DISTRIBUTION MODE}

Volunteer organizations could make up for the drawbacks of market or government, since its own advantage. At the same time, for that reason academia tend to fully affirm organizations' function mostly and neglect their internal defects. Salamon put forward volunteer failure to break down the legend of volunteer organizations. On the one hand, non-governmental organizations' activities are based on voluntary spirit: the services are provided by volunteers, the donation comes from all social sectors. On the other hand, the volunteers who provide services and donation would be driven by self interests because of economic man's nature. Once the members of non-governmental organizations lose the control in the game between morality and self interests, the motive certainly will make them chasing for benefits and honors excessively, leading to volunteer failure. The organizations deviate from voluntary public welfare mechanism engendering low efficient or nonpublic value orientated distribution. Consequently, it comes short in function and efficiency when satisfying social multiple demand or providing public goods and services. All in all, government, market, and social organizations are all significant. If we want to hold a multi-society, the balance among these three 
is indispensible ${ }^{[5]}$.

Facing failure of market, government, and non-governmental organizations in succession, western scholars started to think over handling failures by governance mechanism. Theory of multicenter lays stress on that we should depend on several modes rather than a single distribution mode. Thus, inefficiency or lack of respond to public demand induced by single mode will disappear. Theory of multicenter found another invisible hand besides government and market, and another multicenter order of the way society functions besides market order and national power. It violates the highest authority order chain and power center in single centered mode. However, it forms a three centered power network of nation, society and market to share the function of public service and management and participate in social resources distribution together.

\section{PUBLIC ADMINISTRATION WITH COLLABORATIVE GOVERNANCE: MULTI-CENTERED SOCIAL RESOURCE DISTRIBUTION MODE}

In the post-modern context, government faces with complex, dynamic, and diverse environment. Public issues become more and more complex, while social activities become more and more interdependent. All these magnify the possibility of ungovernability of government, so government is not the only metadiscourse. Actually, government interacts with kinds of social powers, and a discourse is formed to govern together.

As one of the deepest turn of recognition when human looking for solution of social problems, public administration mode with collaborative governance expands the analysis structure of relationship between nation and society, surpasses traditional contrast between liberalism and nationalism, and forms a new mode type of relationship between nation and society. The term of collaborative governance appropriately summarizes the wisdom of interaction between overlapped production levels and several political fields. It breaks down the traditional dichotomy way of thinking in social science, which regard effective management as process of cooperation of two things such as market and plan, public and private sector, political nation and civil society, etc. The traditional way of thinking strives to set up new technology to manage public affairs and highlights that management is cooperation. The public administration with collaborative governance underlines multicenter distribution mode, and argues that various organizations can make up for each other to achieve optimization of resource distribution through the differences among structure, function, and external operation environment.

In the situation of public administration with collaborative governance, modern social resource distribution's multi-subjects - market, government and nongovernmental organizations set up in separate fields, distribute in various methods, and obey different principles. Moreover, they play different roles. The author borrows the concept of private products in western economy, and believes resource with competitiveness and exclusiveness is private resource. Market dominated distribution mode realize free trade through monetary restriction, which is suitable for private resource with clear property right. The basic principle of this mode is fair rules and free. The aim is to maximize the benefits of distribution. The government dominated mode fits the public resource which is possessed by the whole society. It relies on laws and related regulations, and distributes resource through authority organizations' enforcement. The basic principle is governed by law and authority and the target is to achieve the maximization of whole interest of society and social justice. Non-governmental dominated mode distributes resource through demonetized participation, and negotiations, which suited for resource with unclear property rights and among people. The essential principle is mutual understanding based on common ethics, and the goal is social harmony. Three parts are relatively stable in separate fields, have clear division of work. If one part takes a hand in other fields, taking care of things without its business or out of ability, the reasonable order of work division couldn't be formed. Otherwise, if any part didn't carry out or idled at its own responsibility, and take less or bad care of its work, the reasonable order can hardly be shaped, too. Although three distribution methods function separately in different fields, they learn from and influence each other at the same time. Three parts will cooperate together in some way when they cannot separately function remarkably. For instance, some education, culture, and research resource which distributed originally by government could open to society. A new ternary cooperated mode is invested by market and financed by government or provides specialized service by society which charges some proper fees. This new mode is directed, supervised and financed by government, invested by market, and provided with specialized socialized service specifically by non-governmental organizations. Under this new mode, we should build up law framework to restraint and eliminate the randomness of public administration. Once three parts of modern distribution subjects combine with each other, an all-sided social power system can be shaped. Bringing distribution mode into collective ration track could reduce or eliminate many negative phenomenon generated by irrational desire, overcome conflicts from all levels, and construct a mechanism to accomplish social harmony.

\section{CONCLUSION}

With the development of global governance concept and transmutation of normal formulas, since market failure, government failure, and volunteer failure exist at the same time, only one subject would cause waste of resource or anomie of system because of its innate drawbacks. In the context of collaborative governance and service oriented government of public administration normal form, the multicenter distribution mode of collaborative governance could make limited resource achieve the best effect, and realize the maximization of social public goods. 


\section{ACKNOWLEDGMENT}

This research was supported in part by NSFC under Grant 71173004.

\section{REFERENCES}

[1] Jian-Rong Huang. New Theory of Public Administration[M]. Beijing: Social Sciences Academic Press, 2005:41

[2] Douglas. C. North. Structure and Change in Economic History[M]. Shanghai: Shanghai Renmin Press, 1994:175

[3] Tai-Jun Jin. Market Failure, Government Failure and Government Intervention[J]. Journal of Fujian Party School, 2002;(5)52-56.

[4] Hansmann,Henry. The Role of Nonprofit Enterprise. Yale Law Journal,Vol. 1980: 835-901.

[5] Zeng-Ke He. Civil Society and Non-governmental Organizations. Beijing: Social Sciences Academic Press, 2000 